\title{
Phytoplankton response to intermittent stirring and nutrient addition in marine microcosms
}

\author{
Marta Estrada, Celia Marrasé, Miquel Alcaraz \\ Institut de Ciències del Mar, P. NacionaI, s/n, 08003 Barcelona, Spain
}

\begin{abstract}
Eight 301 cylindric culture vessels were filled with sea water from the Masnou Nautical Harbour, Barcelona (Spain), and subjected to different conditions of stirring and nutrient additions. The contents of 4 of the vessels were stirred vigorously for 15 min every 2 to $3 \mathrm{~d}$. Two of the stirred and 2 of the non-stirred vessels received nitrate, phosphate and silicate nutrient additions at the same time intervals. After an initial bloom dominated by centric diatoms, the sequence of phytoplankton assemblages dominating in different phases of the experiments varied according to treatments. In enriched tubes, total numbers of cells and diatoms were much higher than in non-enriched tubes, and the initial bloom involved higher concentrations of large diatoms. Mixing altered the abundance of several species, but its most apparent effect was proliferation and maintenance, in the vessels that also received nutrient additions, of the large-celled diatom Bellerochea yucatanensis.
\end{abstract}

\section{INTRODUCTION}

Physical forcing caused by advective and turbulent water movements is a major determinant of the structure and function of aquatic ecosystems. Margalef (1978) and Bowman et al. (1981) have related the dominant phytoplankton life-forms in the marine environment with the input of external energy manifested as water movement.

As pointed out by several authors, the effects of external energy in aquatic ecosystems depend not only on the intensity of the inputs but also on their frequency characteristics (Platt \& Denman 1975, Kemp \& Mitsch 1979, Margalef 1982, Harris 1983). For example, the particularly high productivity of certain upwelling or estuarine areas has been related to an adequate coupling of hydrodynamical and biological time scales (Legendre 1981). However, in nature, the effects of water movement cannot be separated from those associated with changes in nutrient and light availability. Some encouraging experimental approaches to this problem have been based on the use of meso- or microcosms (Eppley et al. 1978, Smetacek et al. 1980, Oviatt 1981, Donaghay \& Klos 1985), but there has been relatively little work on the interactions between mixing and nutrient input.

In this paper, we describe the response of a marine phytoplankton population enclosed in $30 \mathrm{dm}^{3}$ cylindri- cal microcosms, subjected (in duplicate) to the following treatments: short periods (15 min) of strong mixing every 2 to $3 d_{\text {; }}$ addition of nutrients every 2 to $3 d$; simultaneous mixing and addition of nutrients at the same intervals; and absence of mixing and nutrient additions. The results of later experiments, in which different mixing and nutrient addition schedules were assayed, are reported elsewhere (Marrasé 1986). Previous work with the same type of microcosms addressed the effects of the intensity of small scale turbulence cobtained by means of vertically oscillating disks of Netlon netting) and its interaction with the population density of predators (Estrada et al. 1987, Alcaraz et al. in press).

\section{MATERIAL AND METHODS}

Microcosm setup. The 8 containers employed in the experiment were Perspex cylindrical tubes $(15 \mathrm{~cm}$ diameter, $200 \mathrm{~cm}$ high), placed in a constant temperature chamber at $15^{\circ} \mathrm{C} \pm 1 \mathrm{C}^{\circ}$. On 7 February 1983 , the tubes were filled with sea water taken from the mouth of the Nautical Harbour of Masnou $(20 \mathrm{~km}$ north of Barcelona, Spain) and transported to the laboratory in polyethylene carboys. Before filling the tubes, the water was screened through netting of $150 \mu \mathrm{m}$ mesh size, to exclude the larger zooplankters. Each microcosm was 
illuminated, in a $12 \mathrm{~h}$ (from 08:00 to 20:00 h) light-dark cycle, with eight $20 \mathrm{~W}$ fluorescent lamps, $60 \mathrm{~cm}$ long, 4 of them placed along the upper part, and 4 along the lower part of the tubes; 2 additional $8 \mathrm{~W}$ fluorescent lamps were located above each tube (Fig. 1)

Every 2 or $3 \mathrm{~d}$, at 10:00 h, water samples for nutrient and chlorophyll determinations and phytoplankton counts were siphoned out from $40 \mathrm{~cm}$ depth. After sampling, the water of 4 of the tubes was mixed thoroughly for $15 \mathrm{~min}$ employing air injected from the bottom by a peristaltic pump. At the same time, nutrients were added to 2 of the mixed tubes to increase nutrient concentrations by $10 \mathrm{unol} \mathrm{l}^{-1}$ of $\mathrm{NO}_{3}$ $\mathrm{N}, 1 \mu \mathrm{mol} \mathrm{l} \mathrm{l}^{-1}$ of $\mathrm{PO}_{4}-\mathrm{P}$ and $10 \mu \mathrm{mol} \mathrm{l}^{-1}$ of $\mathrm{SiO}_{4}$-Si. For the additions, the amount of nutrients required was diluted in $2 \mathrm{dm}^{3}$ aliquots of the original Masnou water that had been filtered through Whatman GF/C filters and stored frozen. The same concentrations of nutrients were distributed, on the same days, to 2 of the unstirred tubes; equal amounts of the liquid were introduced at $0,45,100$ and $145 \mathrm{~cm}$ depth, using silicone tubing. The same volume of Masnou water, without nutrients, was added to the 4 remaining tubes. In summary, the treatments applied to the 4 pairs of tubes were: neither mixing nor nutrient addition (Tubes $Q-1$ and Q-2): mixing only (Tubes $M-1$ and $M-2$ ); nutrient addition only (Tubes QN-1 and QN-2); and mixing and nutrient addition (Tubes MN-1 and MN-2). Vertical temperature and photosynthetically active irradiance (PAR) profiles were obtained several times along the experiment using, respectively, a Crison temperature probe and a Lambda LI-192S spherical quantum sensor. The

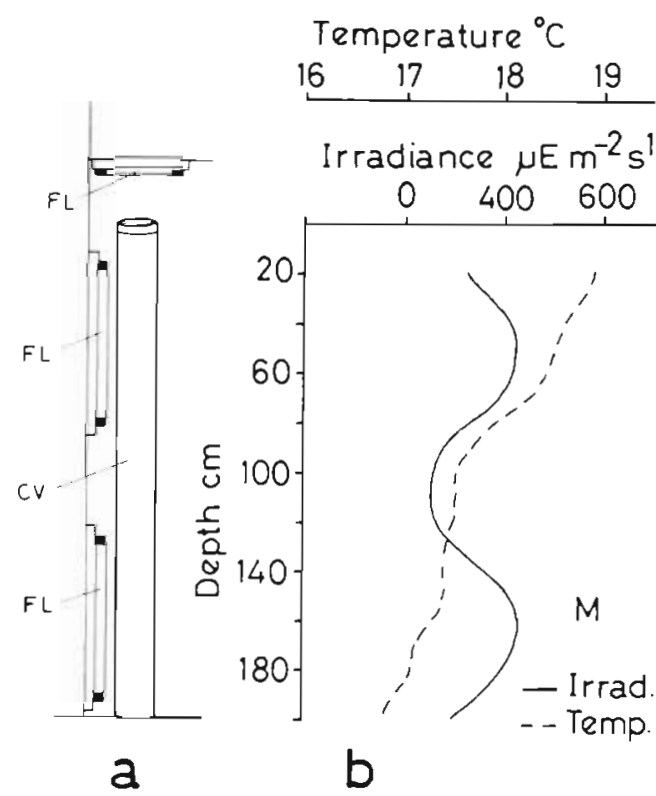

experiment lasted until $25 \mathrm{March}$; an additional sample was taken on 30 March, but due to the larger sampling interval, these data were not included in the statistical analyses.

Chemical and biological determinations. Water subsamples for nitrate, nitrite, phosphate and silicate determinations were frozen immediately after extraction and stored for later analysis on a Technicon Autoanalyzer, using the procedures of Strickland \& Parsons (1972). Due to analytical problems, the nitrate determinations of the first 2 samplings had to be discarded. Chlorophyll a concentration was determined by fluorimetry (Yentsch \& Menzel 1963, Strickland \& Parsons 1972), after filtration of $20 \mathrm{ml}$ of water on Whatman GF/C glass fiber filters and homogenization of the filters in $90 \%$ acetone.

The subsamples for phytoplankton species counts were stored in $20 \mathrm{ml}$ glass bottles and fixed with concentrated Lugol's solution (Margalef 1973). Observations were made as described in Estrada et al. (1987). scanning the bottom of $10 \mathrm{~cm}^{3}$ settling chambers under 125 and $500 \times$, by means of an inverted microscope. Many organisms, particularly small flagellates and naked dinoflagellates, could not be adequately classified and had to be pooled in broad categories such as 'Flagellates' or 'Small dinoflagellates'.

Mathematical methods. The diversity (D) of the phytoplankton assemblages was calculated (Margalef 1957) according to the Shannon-Weaver expression:

$$
\mathrm{D}=-\sum_{i=1}^{n} \mathrm{p}_{i} \log _{2} \mathrm{p}_{11}
$$

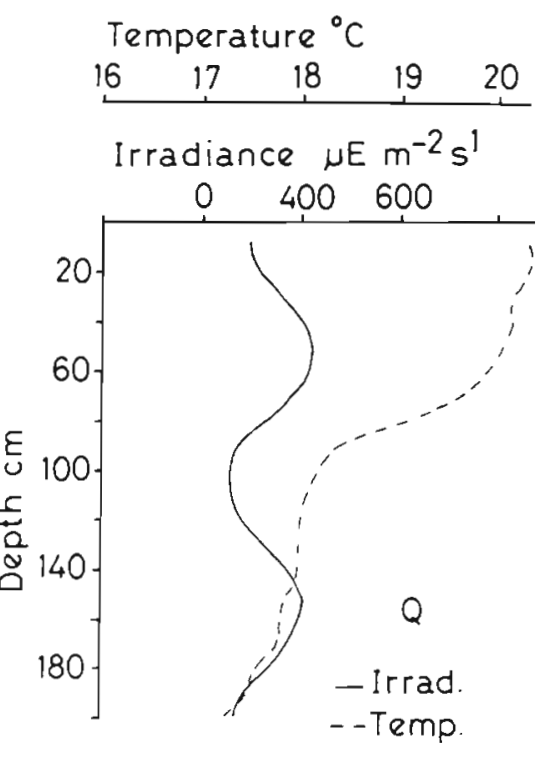

Fig. 1 (a) Microcosm setup. FL = fluorescent lamps, $C V=$ culture vessel. (b) Typical profiles of temperature (temp.) and photosynthetically active radiation (Irrad.) for Tubes Q-1 and 1 [-1. Data taken 6 h after sampling and applying mixing treatment to $M-1$ tube 
where $n=$ number of species (or other taxonomic categories) in the sample; $\mathrm{p}_{i}=$ proportion of individuals of species or category $i$.

To summarize the trends of variability of the phytoplankton data, 2 principal components analyses (e.g. Blasco et al. 1981, Legendre \& Legendre 1983) were performed on the correlation matrices among the abundances (after logarithmic transformation) of the 31 and 42 most frequent taxa. The results obtained were similar, so that comments will be referred to the 42 species analysis. The 31 species data set, divided into 8 classes ( 4 conditions $\times 2$ duplicates) was subjected to a canonical population analysis (e.g. Oviatt et al. 1980, Cuadras 1981, Legendre \& Legendre 1983), to identify the main taxa contributing to the differences among the populations.

The program used for principal component analysis was modified from the IBM Scientific Subroutine Package. The program for canonical population analysis was implemented by C. Cuadras and A. Castellón (pers. comm.). The calculations were carried out on the PDP 11-24 of the Institut de Ciències del Mar of Barcelona.

\section{RESULTS}

\section{Physico-chemical variables}

The temperature in the tubes varied from 17.2 to $17.5^{\circ} \mathrm{C}$ in the bottom of the tubes to 19 to $20^{\circ} \mathrm{C}$ at surface (Fig. 1). The $Q$ (non-mixed) tubes presented a thermocline between 70 and $100 \mathrm{~cm}$ depth and a smaller one from $160 \mathrm{~cm}$ depth to the bottom; the presence of 2 gradient zones was related to the illumination system. In the $M$ (mixed) tubes, the temperature distribution varied with time after mixing; Fig. 1 shows a vertical profile obtained $6 \mathrm{~h}$ after mixing. The values of photosynthetically active irradiance ranged between 100 and $500 \mu \mathrm{E} \mathrm{m}^{-2} \mathrm{~s}^{-1}$ and presented a profile with 2 maxima, at ca 50 and $150 \mathrm{~cm}$, due to the position of the lamps.

The nutrient concentrations decreased at the beginning of the experiment (after Day 4 for phosphate and after Day 6 for silicate), in relation with the development of an initial chlorophyll maximum. In the tubes without nutrient additions, after the initial minimum, phosphate became very low $(0.01 \mu M)$ or undetectable, while nitrate levels oscillated between 0.5 and $3 \mu \mathrm{M}$ and silicate levels between 0.8 and $1 \mu M$. In the enriched tubes, after the initial minimum, phosphate increased first up to about $2 \mu M$ and decreased down to around $0.5 \mu M$ towards the end of the experiment; nitrate concentrations showed marked oscillations but in general did not exceed $4 \mu M$, and silicate tended to increase but showed large variability among duplicates. N/P ratios reached values generally well above 16 (by atoms) in the non-enriched tubes and below 5 in the enriched ones.

\section{Phytoplankton biomass}

In all treatments, the chlorophyll concentration (Fig. 2) attained a maximum on the second sampling (Day 4). This maximum was much higher in tubes with nutrient additions, but there were no obvious differences between $M$ and $Q$ tubes. Following the initial max-
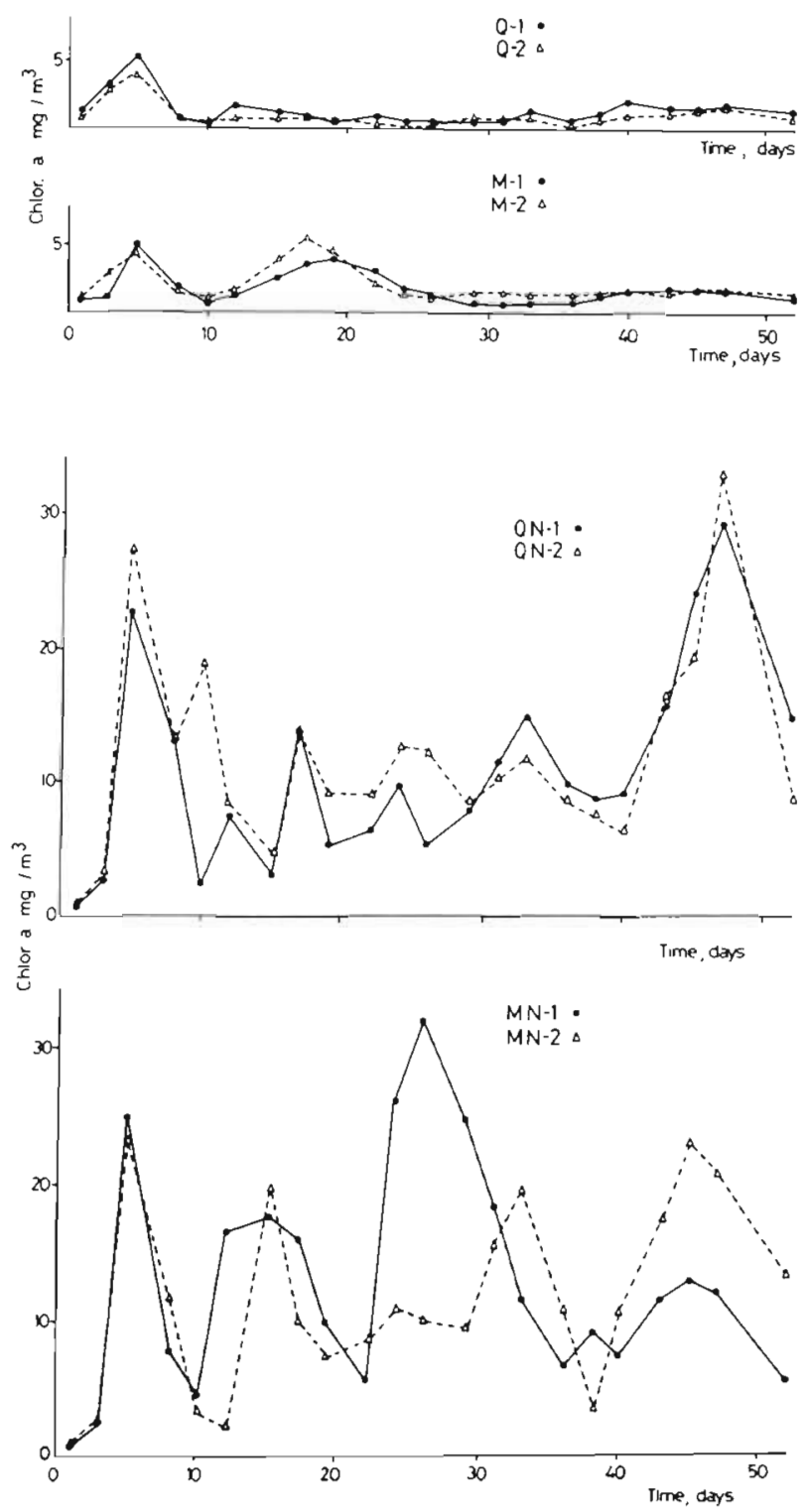

Fig. 2. Upper: Temporal variation of chlorophyll concentration in $Q$ and $M$ tubes. Numbers 1, 2 indicate replicates. Lower: Temporal variation of chlorophyll concentration in $Q N$ and MN tubes. Numbers 1, 2 indicate replicates 

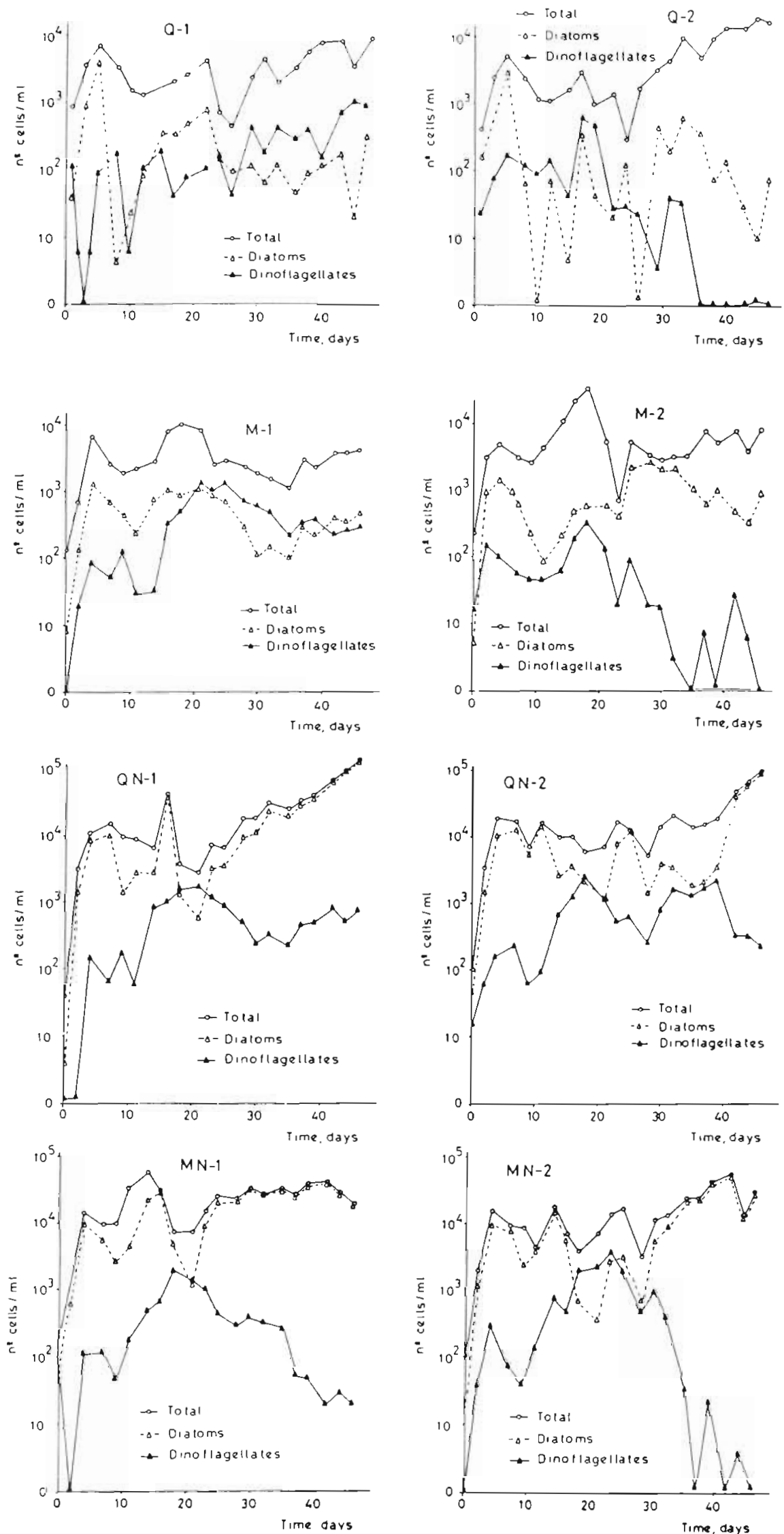

Fig. 3. Temporal variation of the concentration of total phytoplankton diatoms, and dinoflagellates in $Q, M$ QN and MN tubes. Numbers 1, 2 indicate replicates 
imum, chlorophyll patterns in the different tubes differed. QN and MN tubes presented several successive chlorophyll maxima with values which, on occasion, exceeded those of the initial peak. Chlorophyll levels in non-enriched tubes remained much lower than those in enriched ones; within the non-enriched group, $M$ tubes showed a second chlorophyll maximum and, in general, higher chlorophyll concentrations than Q tubes.

Total cell numbers (Fig. 3) exhibited peaks which often coincided in timing with those of chlorophyll, specially during the first phases of the experiment. However, due to lack of estimates of cellular chlorophyll contents, it was difficult to ascertain the contribution of the different species to each chlorophyll maximum. The initial peak was due, in all tubes, to a proliferation of centric diatoms (which included Chaetoceros socialis and Skeletonema costatum) accompanied, in the enriched tubes, by larger-celled species such as $C$. Curvisetus. After this maximum, flagellates, dinoflagellates and coccolithophorids became the most abundant groups in the non-enriched tubes. A large proportion of flagellates was often formed by Chrysochromulina-like haptophytes. In enriched tubes, population maxima of diatoms including $S$. costatum, Chaetoceros spp, and Thalassiosira spp. were the main contributors to the successive chlorophyll peaks during the first half of the experiment. Afterwards, Nitzschia closterium became numerically dominant, and the chlorophyll fluctuations appeared to correspond more to changes in the chlorophyll content of the cells than to fluctuations in cell numbers.

It is interesting to note that the third chlorophyll maximum in the MN-2 tube seemed to be due basically to concentrations up to 1900 cells $\mathrm{cm}^{3}$ of Bellerochea yucatanensis, first described by von Stosch (1977) in waters of the Gulf of Yucatan and found in low numbers in our analysis of some of the original samples taken from Masnou. As far as we know, this is the first mention of the species in the Mediterranean sea. Given the large size and characteristic aspect of this Bellerochea, it is unlikely that it had been overlooked previously, so that it could be a recent acquisition for the Mediterranean flora.

The average concentration throughout the experiment of cells of 4 main phytoplankton groups is listed in Table 1. The value for diatoms was calculated with and without the contribution of the small Thalassiosira spp. and Nitzschia closterium, which were (especially the latter species) numerically dominant in the enriched microcosms. The diversity index (Fig. 4) presented large oscillations and tended to decrease in the course of the experiment, expecially in enriched tubes. The high variability among duplicates made it difficult to recognize differences between experimental treatments; in this context, the information given by the diversity index was very limited. Some trends in diversity variation may have been obscured due to the large number of taxa that had to be pooled in the cell counts; it should be noted also that diversity is related to sample size, and that a proper approach to the interpretation of diversity indices makes it necessary to work with space spectra, rather than with point values of diversity (Margalef 1969).

\section{Statistical analysis}

The first 3 principal components extracted in the analysis of the 42 selected taxa account respectively for 19,11 and $8 \%$ of the total variance. Table 2 lists the correlation coefficients (or loadings) of the taxa on the components. The extremes of the loading range for the first component were occupied, on one side by diatom species associated with the initial bloom, while the species on the other side - which included the diatom Nitzschia closterium - were more abun-

Table 1. Average concentration of cells of 4 main phytoplankton groups throughout the experiment (21 samples). Means \pm standard error of the means. Values for diatoms calculated with and without the contribution of the small Thalassiosira spp. and Nitzschia closterium

\begin{tabular}{|cccccc|}
\hline $\begin{array}{c}\text { Experimental } \\
\text { conditions }\end{array}$ & Dinoflagellates & Total diatoms & $\begin{array}{c}\text { Cells ml } \\
\text { Large diatoms }\end{array}$ & $\begin{array}{c}\text { Coccolithophorids } \\
\text { Flagellates }\end{array}$ \\
\hline Q -1 & $273 \pm 64$ & $392 \pm 188$ & $335 \pm 170$ & $39 \pm 14$ & $1530 \pm 356$ \\
Q -2 & $117 \pm 42$ & $332 \pm 146$ & $226 \pm 131$ & $72 \pm 12$ & $4940 \pm 134$ \\
M - & $447 \pm 99$ & $547 \pm 88$ & $395 \pm 73$ & $184 \pm 63$ & $1380 \pm 230$ \\
M - & $69 \pm 20$ & $1020 \pm 190$ & $858 \pm 178$ & $62 \pm 37$ & $2150 \pm 531$ \\
QN-1 & $619 \pm 117$ & $24600 \pm 7480$ & $1380 \pm 619$ & $1900 \pm 518$ & $939 \pm 215$ \\
QN-2 & $806 \pm 167$ & $12900 \pm 4530$ & $2530 \pm 862$ & $1720 \pm 525$ & $4140 \pm 919$ \\
MN-1 & $405 \pm 118$ & $18800 \pm 2950$ & $4550 \pm 1420$ & $298 \pm 121$ & $1140 \pm 201$ \\
MN-2 & $707 \pm 238$ & $13600 \pm 3840$ & $1893 \pm 589$ & $776 \pm 293$ & $1870 \pm 328$ \\
\end{tabular}



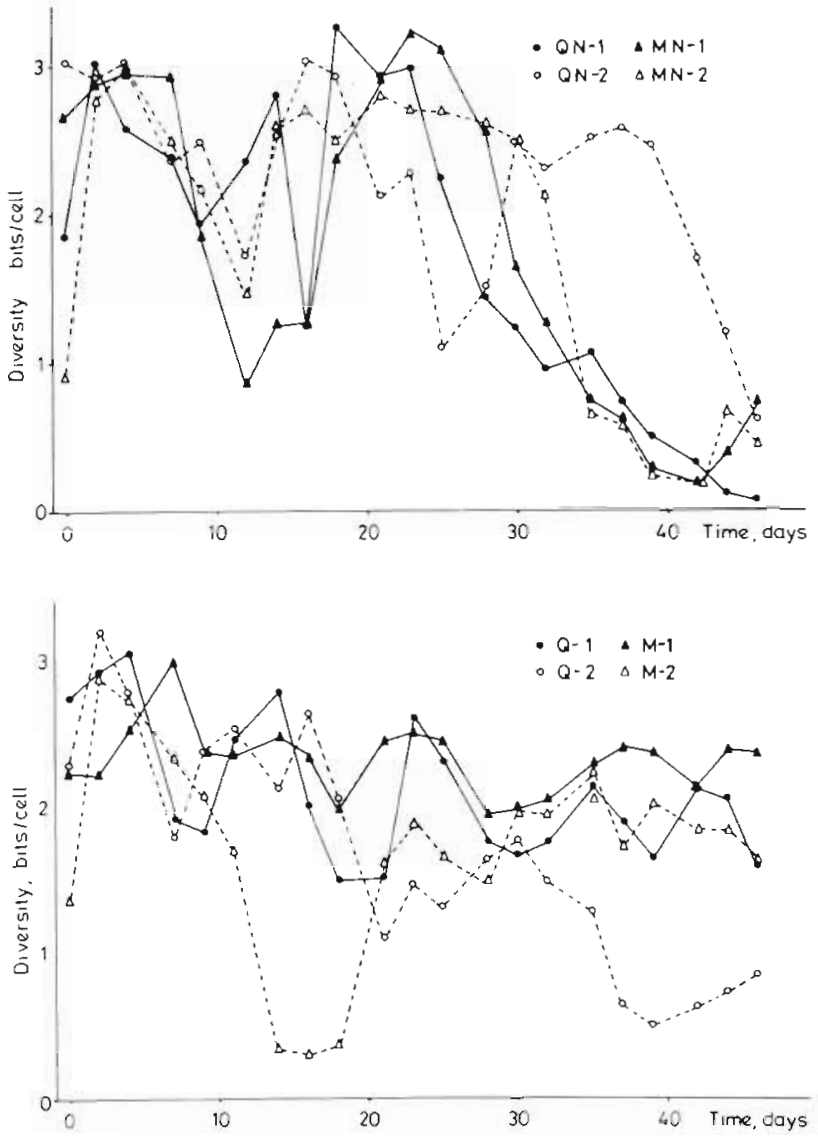

Fig. 4. Temporal variation of Shannon-Weaver diversity index (D) in $\mathrm{Q}, \mathrm{M}, \mathrm{QN}$ and $\mathrm{MN}$ tubes

dant in later phases of the experiments. The second component had the strongest (positive) correlations with several dinoflagellates (Protoperidinium spp., $P$. diabolus, Scrippsiella trochoidea, etc.) the coccolithophorid Emiliania huxleyi, and the diatoms Leptocylindrus danicus and $N$. closterium. The third component presented the highest loadings on one side with Bellerochea yucatanensis, $N$. closterium and 2 groups of pennate diatoms, and on the other side with several dinoflagellate taxa, $L$. danicus and Pterosperma spp.

The temporal evolution of the scores of the first principal component (Fig. 5) attained, in all microcosms, a maximum at the beginning of the experiment, reflecting the initial bloom of centric diatoms. However, size, duration and shape of the maximum varied depending on the treatments. In particular, maximum scores of the component were reached in $\mathrm{MN}$ tubes, but relatively high scores lasted longer in $Q N$ tubes, indicating an increased persistence of the species responsible for the bloom.

The second principal component (Fig. 6) showed almost only negative values in the non-enriched $(Q$ and $M)$ tubes, while in the enriched (QN and MN) ones, the scores increased from the beginning of the experiment, with a maximum around Day 25. There were no obvious differences between $Q$ and $M$ tubes.

The third principal component (Fig. 7) presented an initial peak in all microcosms; thereafter, in $Q$ tubes, it remained near zero until the end of the experiment, while in the remaining tubes, it showed a more or less marked minimum around the Day 18 , followed by a fast increase in $\mathrm{MN}$ and, to a smaller degree, in QN tubes. This is the only component that, after initial changes,

Table 2. Correlation coefficients of the 42 species selected for the analysis with the first 3 principal components. Species arranged according to correlation coefficient with PC 1

\begin{tabular}{|c|c|c|c|}
\hline \multirow[t]{2}{*}{ Species } & \multicolumn{3}{|c|}{ Components } \\
\hline & 1 & 2 & 3 \\
\hline Scrippsiella cf. trochoidea & 0.40 & 0.66 & 0.27 \\
\hline Nitzschia closterium & 0.35 & 0.52 & 0.46 \\
\hline Flagellate ' 383 ' & 0.33 & -0.41 & -0.07 \\
\hline Prorocentrum micans & 0.31 & 0.54 & 0.29 \\
\hline $\begin{array}{l}\text { Desmarella moniliformis? } \\
\text { (Choanoflagellate) }\end{array}$ & 0.26 & -0.09 & 0.06 \\
\hline Pterosperma sp. & 0.23 & 0.25 & -0.40 \\
\hline Prorocentrum balticum & 0.19 & 0.35 & 0.29 \\
\hline Protoperidinium diabolus & 0.17 & 0.59 & 0.06 \\
\hline Protoperidinium spp. & 0.15 & 0.70 & 0.12 \\
\hline Gyrodinium spp. & 0.15 & 0.44 & -0.39 \\
\hline Ceratium furca & 0.13 & 0.24 & -0.11 \\
\hline Small pennate diatoms & 0.12 & 0.35 & 0.44 \\
\hline Large pennate diatoms & 0.11 & 0.13 & 0.23 \\
\hline Bellerochea yucatanensis & 0.05 & 0.31 & 0.55 \\
\hline Chaetoceros cf. simplex & 0.02 & -0.21 & -0.19 \\
\hline Small dinoflagellates & -0.06 & 0.45 & -0.46 \\
\hline Amphidinium sp. & -0.14 & 0.59 & -0.56 \\
\hline Thalassiosira spp. & -0.17 & 0.18 & 0.34 \\
\hline Leptocylindrus danicus & -0.21 & 0.55 & -0.49 \\
\hline Emiliania huxleyi & -0.25 & 0.55 & -0.05 \\
\hline Protoperidinium ovatum & -0.28 & 0.18 & -0.50 \\
\hline Flagellates & -0.28 & 0.26 & 0.07 \\
\hline Haptophytes & -0.28 & -0.08 & -0.39 \\
\hline Navicula sp. & -0.33 & 0.00 & 0.40 \\
\hline Cerataulina pelagica & -0.38 & 0.38 & -0.35 \\
\hline Calycomonas spp. & -0.38 & -0.28 & 0.01 \\
\hline Skeletonema costatum & -0.41 & -0.24 & -0.25 \\
\hline Thalassiosira spp. (small) & -0.46 & 0.41 & 0.09 \\
\hline Thalassionema nitzschioides & -0.49 & -0.02 & -0.01 \\
\hline Green flagellates & -0.51 & 0.20 & 0.19 \\
\hline Rhizosolenia stolterfothii & -0.51 & 0.17 & 0.00 \\
\hline Cryptomonas spp. & -0.53 & 0.27 & 0.20 \\
\hline Amphiprora sp. & -0.53 & 0.00 & 0.43 \\
\hline Chrysophyte & -0.59 & -0.16 & 0.01 \\
\hline Eucampia zodiacus & -0.60 & 0.08 & 0.00 \\
\hline Asterionella japonica & -0.65 & -0.02 & 0.27 \\
\hline Rhizosolenia imbricata & -0.73 & -0.16 & 0.18 \\
\hline Nitzschia spp. & -0.74 & -0.13 & 0.14 \\
\hline Chaetoceros sp. 'A' & -0.75 & 0.31 & -0.21 \\
\hline Ch. curvisetus & -0.87 & 0.16 & -0.10 \\
\hline Nitzschia sp. 'A' & -0.89 & -0.11 & 0.17 \\
\hline Chaetoceros socialis & -0.89 & 0.02 & 0.07 \\
\hline Variance explained \% & 19 & 11 & 8 \\
\hline
\end{tabular}




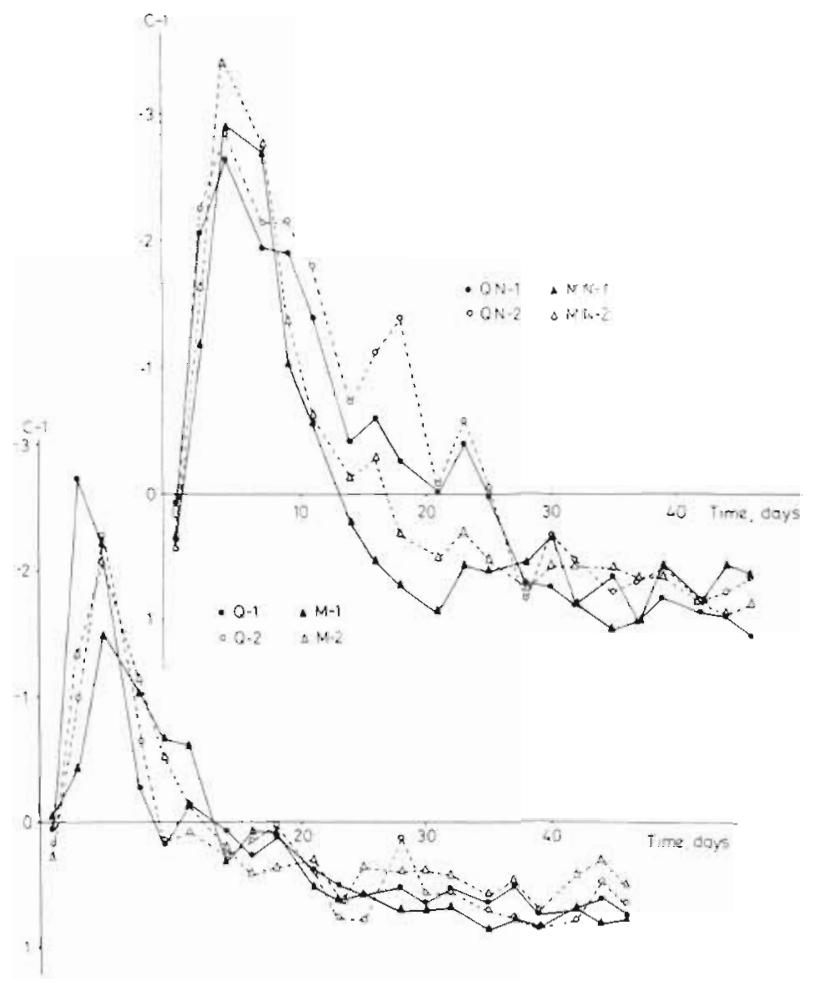

Fig. 5. Temporal variation of values of the first principal component in Q, M, QN and MN tubes. Numbers 1, 2 indicate replicates

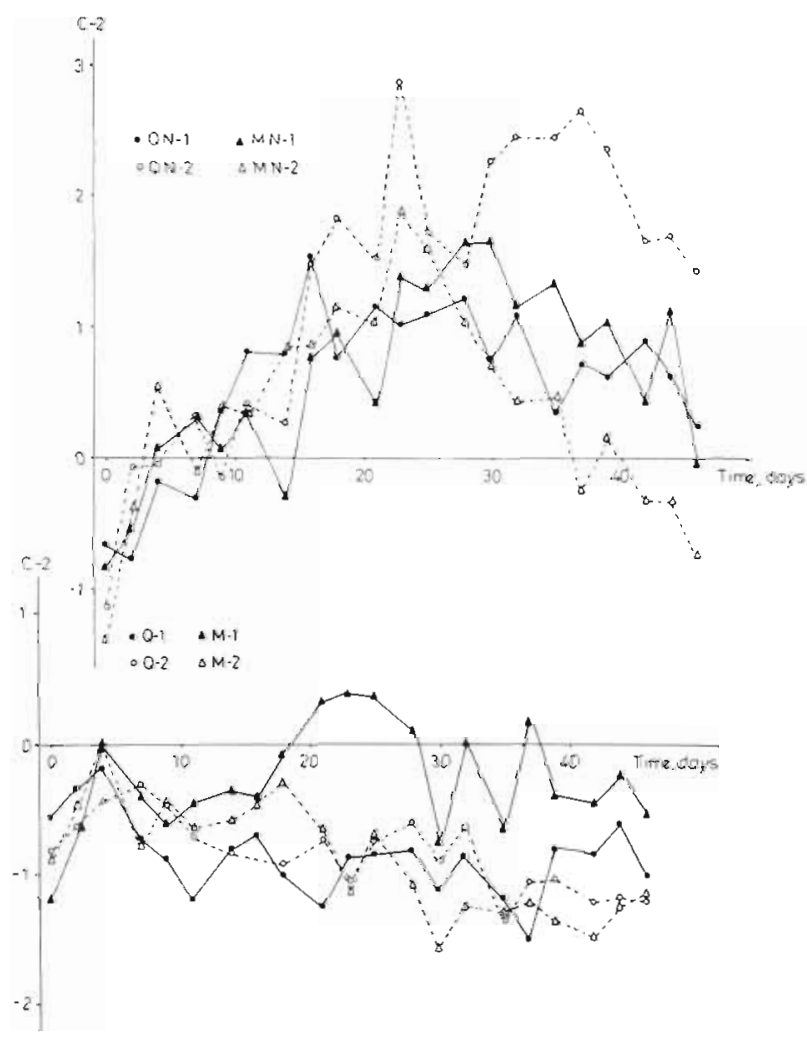

Fig. 6. Temporal variation of values of the second principal component in $Q, M, Q N$ and $M N$ tubes. Numbers 1, 2 indicate replicates

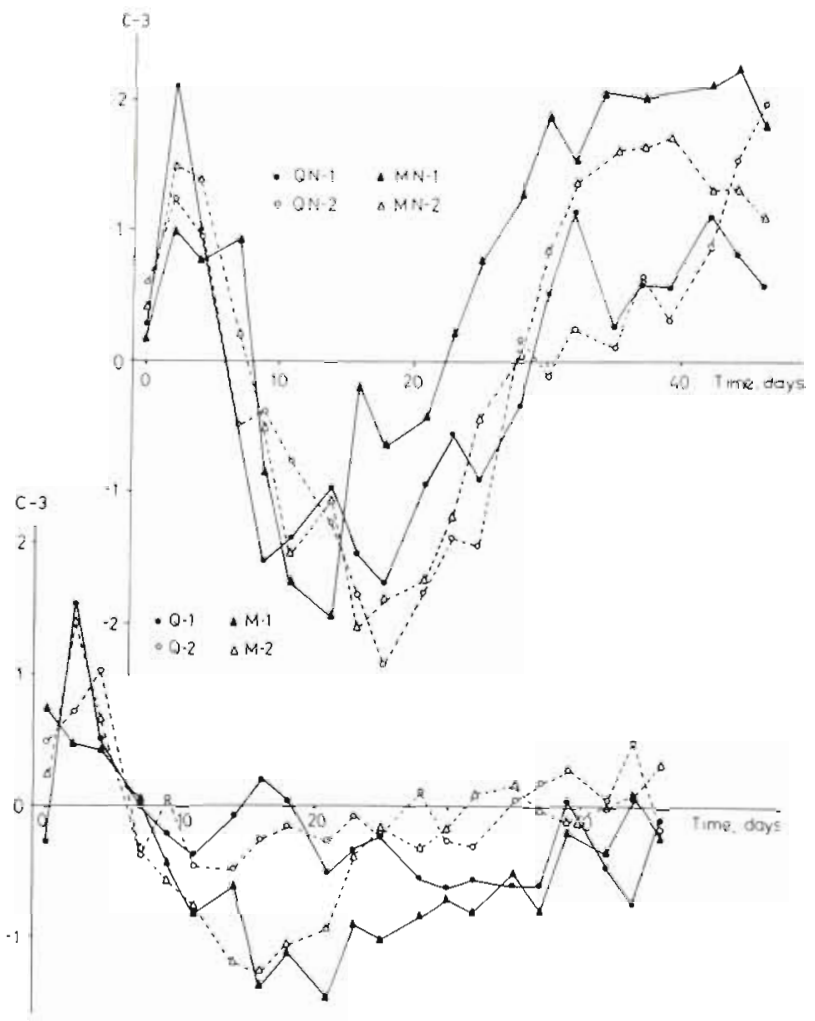

Fig. 7. Temporal variation of values of the third principal component in $Q, M, Q N$ and $M N$ tubes. Numbers 1, 2 indicate replicates

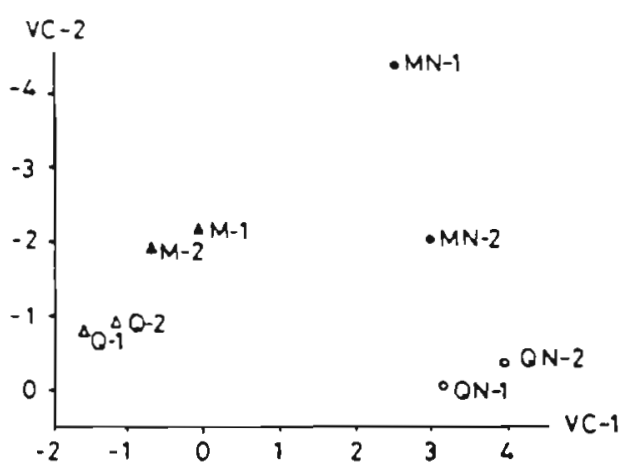

Fig. 8. Position of populations in the space of the 2 first canonical axes

showed consistent differences in phytoplankton composition depending on mixing treatments.

The first 2 axes of the canonical population analysis allowed (Fig. 8) a fairly clear-cut separation of the 8 populations according to treatments, although the distance between the $2 \mathrm{MN}$ duplicates was large. No calculation of significance intervals was attempted, because our data did not fulfill the necessary mathematical assumptions. As can be seen in Fig. 8 , the first axis, explaining $47.5 \%$ of the variance, separated the enriched from the non-enriched microcosms; the second axis, explaining $18 \%$ of the variance, sepa- 
rated the mixed from the non-mixed microcosms. The highest structure coefficients for the first canonical variates (Table 3) corresponded to the diatoms Leptocylindrus danicus, Nitzschia closterium and Bellerochea yucatanensis, to the coccolithophorid Emiliania huxleyi, and to Prorocentrum micans and other dinoflagellate taxa. The only species or groups with coefficients lower than -0.1 were Skeletonema costatum, Calycomonas spp. and the 'Chrysochromulina-like' haptophytes. With respect to the second variate, the highest coefficients were associated with $B$. yucatanensis, $S$. costatum and 2 groups of pennate diatoms.

\section{DISCUSSION}

In many enclosure experiments (Harte et al. 1981, Davis 1982, Estrada et al. 1987) dealing with micro- and mesocosms of different volumes, confinement of the phytoplankton populations triggered a proliferation of

Table 3. Structure coefficients of canonical population analysis of the data set shown in Fig. 8

\begin{tabular}{|lcr|}
\hline \multirow{2}{*}{ Variable } & \multicolumn{2}{c|}{ Canonical axis } \\
& First & Second \\
\hline Amphidinium sp. & & \\
Gyrodinium spp. & 0.21 & -0.09 \\
Prorocentrum micans & 0.20 & -0.09 \\
Protoperidinium ovatum & 0.27 & -0.29 \\
Scrippsiella cf. trochoidea & 0.10 & -0.03 \\
Protoperidinium spp. & 0.24 & 0.16 \\
Small dinoflagellates & 0.23 & 0.05 \\
Emiliania huxleyi & 0.07 & -0.03 \\
Bellerochea yucatanensis & 0.22 & -0.20 \\
Chaetoceros sp. 'A' & 0.23 & 0.48 \\
Chaetoceros curvisetus & 0.19 & -0.17 \\
Chaetoceros socialis & 0.17 & -0.09 \\
Nitzschia closterium & 0.10 & -0.11 \\
Leptocylindrus danicus & 0.25 & 0.06 \\
Nitzschia sp. 'A' & 0.26 & -0.12 \\
Nitzschia spp. & 0.05 & -0.01 \\
Rhizosolenia imbricata & 0.03 & -0.06 \\
Skeletonema costatum & 0.04 & 0.00 \\
Thalassionema nitzschioides & -0.10 & 0.19 \\
Thalassiosira spp. (small) & 0.04 & 0.13 \\
Small pennate diatoms & 0.18 & 0.18 \\
Large pennate diatoms & 0.16 & 0.20 \\
Flagellates & 0.03 & 0.18 \\
Green flagellates & 0.07 & 0.03 \\
Flagellate '383' & 0.10 & -0.08 \\
Calycomonas spp. & -0.22 & -0.02 \\
Chrysophyte & -0.17 & -0.07 \\
Pterosperma sp. & -0.05 & -0.05 \\
Cryptomonas spp. & -0.02 & 0.15 \\
Haptophytes & 0.15 & -0.24 \\
Desmarella moniliformis? & -0.10 & -0.04 \\
(Choanoflagellate) & -0.08 & 0.12 \\
Variance explained \% & & \\
& 47 & 18 \\
\hline
\end{tabular}

centric diatoms. The fact that this phenomenon occurs, when nutrients are available, under varied conditions of irradiance and predator density, suggests that the underlying causes must be very general and may include factors such as effects of initial mixing and reduction of the loss of cells to zones disadvantageous for growth. The influence of nutrient additions on the microcosms was apparent from the beginning of the experiment; the distribution of N/P ratios reflected consistent effects on nutrient utilization and cycling patterns; as expected, biomass expressed as chlorophyll or number of cells, and diatom concentrations were much higher in enriched tubes. The differences between mixed and non-mixed tubes were more subtle, but before discussing them, some methodological comments are pertinent. Bubbling, as stated by Eppley et al. 1978 and Donaghay \& Klos (1985), is not an ideal method to mix the water column, although - as in the work of Eppley et al. (1978) - we adopted it for reasons of expediency. Some of the problems particularly associated with aeration may be the formation or aggregation of particles and changes in the concentration of dissolved gases in the water. However, the bubbling periods were short, compared with the experiment time scale, and we did not see any apparent anomalies or indications of mechanical effects on the organisms. Another shortcoming of this experiment is the comparison of our experimental setup (e.g. choice of PAR profiles or stirring mode) with any particular field situation. Platt et al. (1981) made some pertinent comments concerning a fundamental limitation of many microcosm studies, due to the impossibility of adjusting the biological rates (e.g. of cell division), to compensate for the changes in physical rates derived from the reduction of the physical scales in the system. In this context we point out that our aim was not to make a small-scale reproduction of a natural system, but to investigate potential effects of factors (such as mixing and its energy component) of possible importance in natural environments.

One of the most obvious characteristics of the evolution of chlorophyll in the enriched tubes was the appearance of fluctuations of Iarge amplitude. Especially in MN tubes, the period of these fluctuations was much larger than that of the environmental pulses of mixing and nutrient addition; this type of response, with output oscillations at frequencies different from those of the external forcing, is a typical characteristic of nonlinear systems. The mathematical modelling of nonlinear interactions and their implications for the behaviour of ecosystems have been discussed by various authors (e.g. May 1972, Steele 1974, Platt et al. 1981). The nonlinearity suggested for the response of our microcosms agrees with the conclusions of Dwyer \& Perez (1983), who found that $150 \mathrm{I}$ microcosms derived 
from Narragansett Bay showed periodicities different from the 0.1 cycles $d^{-1}$ variation in the stirring paddle rotation speed used as a forcing function. Another point concerns the comparison between the variations of a global parameter such as chlorophyll concentration and the changes in the specific composition of the community; except for the initial biomass peak, the composition of the phytoplankton in the microcosms, as reflected by the scores of the first principal components, varied much more smoothly than chlorophyll concentration or total cell numbers. In fact, the temporal evolution of the principal components in all microcosms suggested that, from the beginning of the experiment, there was a gradual successional trend in the phytoplankton community. Most of the species forming the bulk of the initial diatom bloom did not reappear, in spite of repeated mixing and nutrient enrichment. Perhaps some factors necessary for their growth had been exhausted in the tubes, but a more general explanation may be related to the spectrum of environment fluctuations. In nature, the centric diatoms of the initial bloom are typical of high external energy conditions (Margalef 1978). They proliferate in response to more intense and relatively less frequent disturbances - such as upwelling pulses, breaking of the thermocline in spring, or confinement in microcosms - which allow high growth rates or reduce losses to non-favourable zones. Probably, the limited spectrum of frequency and intensity of environmental forcing in our tubes did not provide adequate conditions to maintain these diatoms. The decreasing trend of the diversity index could also be related to this environmental impoverishment, although the contribution of artifacts due, for example, to increased participation of non-identifiable forms pooled in the 'flagellate' group, cannot be excluded.

Variation of average values for each pair of duplicates of the parameters in Table 1 showed some unexpected results. Total number of cells and of diatoms was indeed much higher in enriched than in non-enriched tubes, but within each of these groups mixing had different effects. In the non-enriched tubes, average total cell and diatom numbers were higher in stirred tubes; the opposite occurred in enriched tubes. This result was basically due to the high abundances of Nitzschia closterium and small-sized Thalassiosira spp. in QN tubes. This observation suggests that in environments of low turbulence, but with adequate nutrient supply, small-sized diatoms, such as these and Skeletonema costatum, could have some advantages not only over larger diatoms with higher sedimentation rates, but also over dinoflagellates and other groups.

The sequence of assemblages predominating in different stages of the experiment varied according to treatments. The strongest influence on species compos- ition was exerted by nutrient availability. In enriched tubes, the initial bloom included relatively higher concentrations of large diatoms (such as Chaetoceros curvisetus or Chaetoceros $\mathrm{sp}$. A) than in non-enriched ones. Larger mean cell sizes in nutrient-rich environments are consistent with the conclusions of other authors (Malone 1971, Parsons \& Takahashi 1973, Hecky \& Kilham 1974). However, the concentrations of the large diatoms lasted longer in $\mathrm{QN}$ than in $\mathrm{MN}$ tubes, a fact that is reflected in the negative coefficient of these species for the second variate of the canonical population analyses. The taxa showing the highest positive correlations with the second principal component, which characterized the intermediate phases of the experiment in the enriched tubes, included several dinoflagellates, 2 diatoms - 1 'large' (Leptocylindrus danicus) and 1 'small' (Nitzschia closterium) - and 1 coccolithophorid, so that it is difficult to find simple explanations for their response.

Mixing altered the abundance of several species, but its most spectacular effect was the proliferation and maintenance, in MN microcosms, of the large-celled Bellerochea yucatanensis. This agrees with the results of Semina (1968), who found that the average cell or particle size was directly related to the upward velocity of the water. Margalef (1974), dealing with data obtained off NW Africa, concluded also that the average particle size was larger in the zone of coastal upwelling, and Eppley et al. (1978) reported that a brief daily stirring of 2 enclosed columns of coastal sea water led to the maintenance of larger phytoplankton cells than in 2 unstirred columns. However, we feel that until more data on microcosm work are available, generalizations concerning the effects of experimental treatments must be made with caution.

Acknowledgements. We thank R. Margalef for suggestions on experiments and manuscript, and E. Barrenechea, director of the Nautical Harbour of Masnou, for help in initial sea water sampling. C. Duarte made helpful comments on the text, and C. Bas, J. Biosca and M. Vélez provided technical assistance. This work was supported by the Comision Asesora de Investigación Científica y Técnica (grant no. 3246/79) and the Consejo Superior de Investigaciones Científicas.

\section{LITERATURE CITED}

Alcaraz, M., Estrada, M., Marrasé, C. (in press). Interaction between turbulence and zooplankton in marine microcosms. Proceedings of the 21st European Marine Biology Symposium, Gdansk, Poland

Blasco, D., Estrada, M., Jones, B. H. (1981). Short time variability of phytoplankton populations in upwelling regions. The example of northwest Africa. In: Richards, F. A. (ed.) Coastal upwelling. American Geophysical Union, Washington, p. 339-347

Bowman, M. J., Wayne, E. E., Schnitzer, M. B. (1981). Tidal 
stirring and the distribution of phytoplankton in Long Island and Block Island Sounds. J. mar. Res. 39: 587-603

Cuadras, C. (1981). Métodos de análisis multivariante Eunibar, Barcelona

Davis, C. O. (1982). The importance of understanding phyto plankton life strategies in the design of enclosure experiments. In: Grice, G. D., Reeve, M. R. (eds.) Marine mesocosms. Biological and chemical research in experimental ecosystems. Springer-Verlag, New York, p. 323-332

Donaghay, P. L., Klos, E. (1985). Physical, chemical and biological responses to simulated wind and tidal mixing in experimental marine ecosystems. Mar. Ecol. Prog. Ser. 26: $35-45$

Dwyer, R. L., Perez, K. T (1983). An experimental examination of ecosystem linearization. Am. Nat. 121: 305-323

Eppley, R. W., Koeller, P., Wallace Jr, G. I (1978). Stirring influences the phytoplankton composition within enclosed columns of coastal sea water. J. exp. mar. Biol. Ecol. 32: 219-239

Estrada, M., Alcaraz, M., Marrasé, C. (1987). Effects of turbulence on the composition of phytoplankton assemblages in marine microcosms. Mar. Ecol. Prog. Ser. 38: 267-281

Harris, G. P. (1983). Mixed layer physics and phytoplankton populations: studies in equilibrium and non-equilibrium ecology. Prog. Phycolog. Res. 2: 1-52

Harte, J., Levy, D., Ress, J., Saegebath, E. (1981). Making microcosms an effective assessment tool. In: Giesy, J. P. (ed.) Microcosms in ecological research. Technical Information Center, U. S. Dept of Energy, USA, p. 105-136

Hecky, R. E., Kilham, P. (1974). Environmental control of phytoplankton cell size Limnol. Oceanogr. 19: 361-366

Kemp, W. M., Mitsch, W. J. (1979). Turbulence and phytoplankton diversity: a general model of the paradox of plankton. Ecol. Modelling 7: 201-222

Legendre, L. (1981). Hydrodynamic control of marine phytoplankton production. The paradox of stability. In: Nihoul, J. C. J. (ed.) Ecohydrodynamics. Elsevier, Amsterdam, p. $191-197$

Legendre, L., Legendre, P. (1983). Numerical ecology Elsevier, Amsterdam

Malone, T. C. (1971). The relative importance of nannoplankton and netplankton as primary producers in tropical and neritic phytoplankton communities. Limnol. Oceanogr 16 : $633-639$

Margalef, R. (1957). La teoría de la información en ecología. Mem. Real Acad. Cienc. Artes Barcelona 32: 373-449

Margalef, R. (1969). Diversity and stability: a practical proposal and a model of interdependence. Brookhaven Symposia in Biology (Brookhaven National Laboratory, Upton, New York) 22: 25-37

Margalef, R. (1973). Fitoplancton marino de la región de alfloramiento del NW de África. Res. Exp. Cient. B/O Cornide 2: 65-94

Margalef, R. (1974). Distribution du seston dans la région d'affleurement du nord-ouest de l'Afrique en mars 1973 Téthys 6: 77-88

Margalef, R. (1978). Life-forms of phytoplankton as survival alternatives in an unstable environment. Oceanologica Acta 1. 493-509

Margalef, R. (1982). Instabilities in ecology. In: Casas-Vázquez, J, Lebon, G. (eds.) Stability of thermodynamic systems. Lecture Notes in Physics 164, Springer-Verlag, New York, p. 295-306

Marrasé, C. (1986). Experimentos multifactoriales con plancton marino en microcosmos. Ph. D. thesis, University of Barcelona

May, R. M. (1972). Limit cycles in predator-prey communities. Science 177: 900-902

Oviatt, C. A. (1981). Effects of different mixing schedules on phytoplankton, zooplankton and nutrients in marine microcosms. Mar. Ecol. Prog. Ser. 4: 57-67

Oviatt, C. A., Walker, H., Pilson, M. E. Q. (1980). An exploratory analysis of microcosm and ecosystem behavior using multivariate techniques. Mar. Ecol. Prog. Ser. 2: 179-191

Parsons, T. R., Takahashi, M. (1973). Environmental control of phytoplankton cell size. Limnol. Oceanogr 18: 511-515

Platt, T., Denman, K. L. (1975). A general equation for the mesoscale distribution of phytoplankton in the sea. Mémoires de la Societé Royale de Sciences de Liège (6th Series) 8: 31-42

Platt, T., Mann, K. H., Ulanowicz, R. E. (1981). Mathematical models in biological oceanography. The Unesco Press. Paris

von Stosch, H. A. (1977). Observations on Bellerochea and Streptotheca, including descriptions of three new planktonic diatom species. In: Simonsen, R. (ed.) Fourth Symposium on recent and fossil marine diatoms. Nova Hedwigia Beih. 54: 113-166

Smetacek, V., von Bodungen, B., Knoppers, B., Neubert, H., Pollehne, F., Zeitzschel, B. (1980). Shipboard experiments on the effect of vertical mixing on natural plankton populations in the central Baltic sea. Ophelia (Suppl.) 1. 77-98

Steele, J. H. (1974). Spatial heterogeneity and population stability. Nature, Lond. 248: 83

Semina, H. J. (1968). Water movement and the size of phytoplankton cells. Sarsia 34: 267-272

Strickland, J. D. H., Parsons, T R. (1972). A practical handbook of seawater analysis. 2nd edn. Bull. Fish. Res. Bd Can. 167: 1-310

Yentsch, C. S., Menzel. D. W. (1963). A method for the determination of phytoplankton chlorophyll and phaeophytin by fluorescence. Deep Sea Res. 10: 221-231 